\title{
ОСОБИСТІСНІ ВЛАСТИВОСТІ СЛУХАЧА ЯК ПЕРЕДУМОВА ПРОФЕСІЙНОГО СТАНОВЛЕННЯ ТА УСПІШНОЇ АДАПТАЦІЇ ВІЙСЬКОВОГО МЕДИКА
}

\author{
І.С. Трінька' ${ }^{1}$ В.В. Кальниш ${ }^{1}$, Н.I. Мудрик¹, В.О. Волошин ${ }^{2}$ \\ 1Українська військово-медична академія, м. Київ, Україна \\ ${ }^{2}$ Національна академія Служби безпеки України, м. Київ, Україна
}

\begin{abstract}
Вступ. Професійна підготовка особистості військового лікаря $\epsilon$ динамічним процесом професійного самовизначення, пов'язаним з особистісними кризовими явищами. Причинами внутрішньо особистісних конфліктів у процесі здобуття професійної освіти є низький адаптивний рівень психічних можливостей особистості, який не відповідає вимогам навчально-виховної діяльності і проявляється у високому рівні тривожності, агресивності.
\end{abstract}

Метою дослідження було визначення особистісних характеристик та перевірка рівня адаптаційних можливостей слухачів - майбутніх військових лікарів.

Матеріали і методи. Використовувалась методика багатофакторного дослідження особистості Р. Кеттела (16 РF опитувальник). Статистичний аналіз отриманих результатів опитування 135 слухачів проводився методом варіаційної статистики та кластерного аналізу.

Результати. Експериментальні дані з допомогою кластерного аналізу методом k-середніх були поділені на дві підгрупи з різними психологічними характеристиками за комплексом особистісних якостей, які умовно були названі «активні» та «обережні». Встановлено, що слухачі підгрупи «обережних» характеризуються як більш вразливі до невдач, обережні, з сильним почуттям обов'язку, чутливі до оцінки оточуючих, дещо усамітнені, мають достовірно вищі результати навчання в порівнянні з слухачами підгрупи «активних», а слухачі підгрупи «активних» $є$ більш комунікабельними, що є певною перевагою для військової служби. Для представників цієї підгрупи більшу увагу потрібно приділяти якості їх навчання. Показано, що визначені у слухачів особистісні характеристики в цілому підтверджують наявність у них професійно значимих для військового медика рис характеру: самовпевненість, високі розумові здібності, кмітливість, наявність абстрактного мислення, товариськість, домінантність, стриманість, емоційна стійкість, самостійність, незалежність в судженнях та в поведінці, усвідомлена висока нормативність поведінки, осмислене дотримання норм і правил, наполегливість у досягненні мети, відповідальність, мужність, розсудливість, довірливість, доброзичливість щодо інших людей.

Висновки. Запропоновано актуальні шляхи подальшого удосконалення навчального процесу та управління процесом формування професійного світобачення у слухачів факультету підготовки військових лікарів Української військово-медичної академії.

Ключові слова. професійне самовизначення, професійні експектації, професійне становлення військового медика, особистісні властивості, опитувальник Кеттела, професійно значимі риси.

Вступ. Сучасні педагогічно-виховні технології навчання обумовлені необхідністю формування належного рівня адаптаційних можливостей у випускників вищої школи у глобалізованому просторі. За твердженням сучасних науковців, професійна підготовка особистості є динамічним процесом професійного самовизначення. Процес цей складний і обумовлений певними кризовими явищами особистості випускника, насамперед внаслідок кризи професійного самовизначення, професійних експектацій, професійних деструкцій. $\mathrm{y}$ психологопедагогічній літературі сучасні дослідники (М. Боришевський, В. Каземіренко, Л. Губерський, В.Заїка, Л.Малинович, В. Оржеховська, $\epsilon$. Причепій, М. Ходаківський, I. Шаповалова, I. Щербакова) $[1,4,6,8]$ обгрунтовують потребу подолання кризи особистості на шляху іï професійного становлення і визначають ії як духовну кризу особистості. Духовна криза розглядається ними як наслідок накопичення негативного психоенергетичного потенціалу від нерозв'язаних життєво важливих проблем, суперечностей або подій, що спричинили втрату сенсу попереднього стилю життя, поведінки, діяльності. Причинами внутрішньо особистісних конфліктів у процесі здобуття професійної освіти, як правило, $\epsilon$ низький адаптивний рівень психічних можливостей особистості, який не відповідає вимогам навчально-виховної діяльності, що проявляється у високому рівні тривожності, агресивності $[2,5,7]$.

Мета дослідження. Метою нашого дослідження була перевірка рівня адаптаційних можливостей слухачів першого курсу факультету підготовки військових 
лікарів (ФПВЛ) Української військовомедичної академії (УВМА), рівень їх тривожності, невпевненості, агресивності чи навпаки рівень відчуття комфортності i пізнавальної активності, як передумову успішного професійного становлення.

На нашу думку, адаптаційні проблеми надзвичайно актуальні саме для слухачів першого курсу. По-перше, у зв'язку 3 входженням в нову для них мілітарну структуру, по-друге, у зв'язку з особливостями отримання військово-медичного фаху, потретє, з можливостями отримання практичних умінь та навичок військової медицини. Крім того, адаптаційні можливості слухачів можуть бути ще більш ускладнені в сучасних умовах вимушеного дистанційного навчання, що обумовлено епідемією COVID-19. Визначення й врахування у навчально-виховному процесі особистісних якостей слухачів ФПВЛ УВМА, з одного боку, дасть змогу поліпшити ефективність навчання, а з іншого - створить передумови для своєчасного виявлення та усунення дезадаптаційних станів у слухачів.

\section{Матеріали і методи дослідження.}

3 метою визначення особистісних властивостей слухачів була використана методика багатофакторного дослідження особистості Р. Кеттела (16 PF опитувальник) [3]. У дослідженні взяли участь 135 слухачів першого курсу. Статистичний аналіз отриманих результатів проводився методом варіаційної статистики та кластерного аналізу (метод $k$-середніх).

Результати дослідження та їх обговорення. Результати виявлених факторів наведені у табл. 1. Аналіз цих даних дає змогу стверджувати, що досліджувана група слухачів не $\epsilon$ «монолітною». Спостерігаються певні відхилення значень факторів, які можна трактувати як погіршення «нормативних» характеристик особистості у окремих слухачів. Так, фактор MD визначає «адекватність самооцінки» опитуваного. Показник норми визначається в межах $6,7 \pm 1,74$ балів. Середній показник серед слухачів складав 7,75 балів, що свідчить про адекватну самооцінку. Але у 59 слухачів показник самооцінки був вищий 9 балів і чим вища оцінка за цим фактором, тим людині більше властиво завищувати свої можливості і переоцінювати себе. У 25 слухачів показник фактору MD був нижчий 5 балів, що свідчить про їх невпевненість у собі.

Результати багатофакторного дослідження особистості, в балах

\begin{tabular}{|c|c|c|c|c|c|c|}
\hline \multirow[b]{2}{*}{ Фактори } & \multicolumn{6}{|c|}{ Результати } \\
\hline & $\mathrm{MT} \pm \sigma$ & $\mathrm{Me} \pm \sigma$ & Variance & Median & Mode & $\begin{array}{l}\text { Частота (кількість } \\
\text { повторень на рівні } \\
\text { моди) }\end{array}$ \\
\hline $\mathrm{MD}$ & $6,7 \pm 1,74$ & $7,75 \pm 2,41$ & 5,83 & 8,0 & 9,0 & 22 \\
\hline$A$ & $8,06 \pm 1,7$ & $9,89 \pm 2,41$ & 5,82 & 10,0 & 11,0 & 26 \\
\hline $\mathrm{B}$ & $4,5 \pm 0,99$ & $4,38 \pm 1,29$ & 1,66 & 4,0 & 5,0 & 39 \\
\hline $\mathrm{C}$ & $7,5 \pm 1,77$ & $6,50 \pm 1,71$ & 2,93 & 6,0 & 5,0 & 29 \\
\hline$E$ & $5,5 \pm 1,66$ & $6,87 \pm 2,44$ & 5,99 & 7,0 & 6,0 & 23 \\
\hline $\mathrm{F}$ & $5,6 \pm 1,68$ & $6,42 \pm 2,08$ & 4,35 & 6,0 & 6,0 & 28 \\
\hline $\mathrm{G}$ & $7,8 \pm 1,92$ & $9,21 \pm 2,11$ & 4,46 & 10,0 & 10,0 & 35 \\
\hline $\mathrm{H}$ & $7,7 \pm 1,89$ & $8,68 \pm 2,27$ & 5,15 & 9,0 & 8,0 & 26 \\
\hline I & $7,6 \pm 1,68$ & $6,20 \pm 2,13$ & 4,56 & 6,0 & 7,0 & 25 \\
\hline $\mathrm{L}$ & $4,3 \pm 1,54$ & $4,32 \pm 1,93$ & 3,74 & 4,0 & 4,0 & 27 \\
\hline $\mathrm{M}$ & $5,5 \pm 1,63$ & $5,50 \pm 2,32$ & 5,38 & 6,0 & 7,0 & 26 \\
\hline $\mathrm{N}$ & $5,5 \pm 1,63$ & $4,60 \pm 1,94$ & 3,79 & 4,0 & 4,0 & 37 \\
\hline 0 & $6,6 \pm 2,14$ & $5,46 \pm 2,85$ & 8,13 & 6,0 & 6,0 & 22 \\
\hline Q1 & $8,1 \pm 1,33$ & $7,39 \pm 2,16$ & 4,68 & 7,0 & 6,0 & 28 \\
\hline Q2 & $5,8 \pm 1,69$ & $4,79 \pm 2,25$ & 5,07 & 5,0 & 4,0 & 25 \\
\hline Q3 & $6,3 \pm 1,66$ & $8,49 \pm 1,70$ & 2,92 & 9,0 & 10,0 & 32 \\
\hline Q4 & $6,0 \pm 1,74$ & $4,80 \pm 2,45$ & 6,02 & 5,0 & 4,0 & 26 \\
\hline
\end{tabular}

Примітка: Мт $\pm \sigma$ - стандартизовані бали за факторами опитувальника; Ме $\sigma \sigma-$ експериментально визначені бали; Фактори тесту Р.Кеттела: MD - адекватність самооцінки; А - замкнутість-товариськість; В - інтелект; C - емоційна нестійкість - емоційна стійкість; Е - підпорядкованість-домінантність; F стриманість-експресивність; G - підвладність почуттям-висока нормативність поведінки; Н - нерішучістьсміливість; I - жорстокість-чутливість; L - довірливість-підозріливість; M - практичність-розвинута уява; N - прямолінійність-дипломатичність; O - впевненість у собі-тривожність; Q1 - консерватизм-радикалізм; $\mathrm{Q}_{2}$ - конформізм-нонконформізм; $\mathrm{Q}_{3}$ - низький самоконтроль-високий самоконтроль; $\mathrm{Q}_{4}$ - розслабленнянапруженість. Інтелектуальні характеристики B, M, Q1. Емоційно-вольові характеристики C, G, I, O, Q3, Q4. Комунікативні характеристики A, H, F, E, Q2, N, L. 
Фактор А «замкнутість-товариськість» орієнтований на визначення комунікабельності людини в малих групах. Середній показник для слухачів становить 9,89 балів, що $\epsilon$ вищим від верхньої межі норми (9,76 балів). Такий результат свідчить, що в основному слухачі відкриті до спілкування, товариські і доброзичливі у ставленні до оточуючих, природні і невимушені у поведінці та стосунках. Вони охоче співпрацюють у колективі та малих групах, активні, довірливі, переживають яскраві емоції, відгукуються на будь-які події, готові долати конфлікти. Із загальної кількості опитуваних тільки 12 слухачів мали показник А нижчим нижньої межі норми - 6,37 балів, що характеризує їх як малокомунікабельних, замкнених, скептично налаштованих, стриманих у стосунках, таких, що люблять усамітненість.

Середні експериментальні результати фактору В у слухачів, що визначає «інтелект» опитуваного, посередні - 4,38 бали. Це дещо нижче стандартизованого показника Мт=4,5 $\pm 0,99$, але в межа норми. Такий показник може свідчити про конкретність та деяку ригідність мислення. Середній бал диплому вступника до академії становить близько 4 балів. Тільки у 26 слухачів тестовий показник $\mathrm{B} \geq 6$ бали, що свідчить про загальні високі розумові здібності, кмітливість, наявність абстрактного мислення.

Експериментально визначене значення фактору C=6,5 бали свідчить про частково знижену толерантність до фрустрації, підвладність почуттям, мінливість інтересів, схильність до лабільності настрою, деяку роздратованість, стомлюваність.

У 38 слухачів показник фактору С був вище 8 балів, що дає можливість характеризувати їх як стриманих, працелюбних, емоційно зрілих, реалістично налаштованих. Вони здатні наслідувати вимоги групи, характеризуються стійкістю інтересів, відсутністю нервовопсихологічного напруження.

Отримане експериментальне значення фактору E=6,87 бали (підпорядкованістьдомінантність) $€$ вищим від середнього тестового значення. Це свідчить, що слухачам притаманні такі риси як самовпевненість, незалежність в судженнях та в поведінці, непоступливість у дотриманні власної думки, схильність нав'язувати їі оточуючим, іноді агресивність, не визнання влади над собою і тиску ззовні i, на противагу, визнання власного авторитарного стилю керівництва, відстоювання власного статусу. Тільки у 23 слухачів Е $\leq 4$ балів, що свідчить про сором'язливість, поступливість, залежність від інших, тривожність щодо можливих своїх помилок. Таким особам властиві тактовність, безвідмовність, шанобливість, покірність.

Фактор F (стриманість-експресивність) $\mathrm{F}=6,42$ бали, що відображає емоційну забарвленість i динамічність спілкування, відповідає верхній межі норми і характеризує слухачів як життєрадісних, енергійних, безпечних, веселих, говірких. Соціальні контакти для них будуть емоційно значимі, у стосунках з людьми вони щирі, експансивні. Емоційність, динамічність спілкування сприяють тому, що вони можуть ставати лідерами і організаторами групової діяльності, вірять в удачу.

Експериментально визначений показник фактору G (підвладність почуттям-висока нормативність поведінки) для слухачів дуже високий i становить 9,21 бали (тестові показники 7,8 1,92 ), що означає усвідомлену високу нормативність поведінки, осмислене дотримання норм і правил, наполегливість у досягненні мети, точність, відповідальність, ділову спрямованість особистості.

Високим у слухачів виявився експериментально визначений показник фактору $\mathrm{H}$ (нерішучість-сміливість) - 8,68

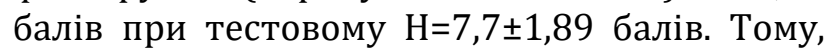
слухачів можна охарактеризувати як сміливих, активних, вільних у стосунках, готових до нових обставин і знайомств, схильних до ризиків. Тільки у 7 слухачів показник фактору $\mathrm{H} \leq 6$ балів, що виходить за межі норми $\mathrm{i}$ свідчить про надмірну нерішучість, невпевненість у своїх силах, стриманість, підвищену чутливість до погроз, бажання перебувати «в тіні».

Показник фактору I (жорстокість чутливість) становить I=6,2 бала, $\epsilon$ нижчим тестового значення 7,6 $\pm 1,68$ бала, що вказує на мужність, самовпевненість, розсудливість, реалістичність суджень слухачів, їх практичність, жорстокість, суворість, певну черствість. Тільки у 19 слухачів показник виявився I $\geq 9$ балів, що свідчить про м'якість натури, схильність до романтизму, артистичність натури, жіночність, художнє сприйняття світу. Можна говорити про здатність до емпатії, співчуття, співпереживання і розуміння інших людей. Слід врахувати, що серед опитуваних майже половина - 58 осіб є особами жіночої статі.

Експериментальне значення фактору $\mathrm{L}=4,32$ бала (довірливість-підозрілість) 
відповідає нормі тесту. При низьких оцінках людина характеризується відвертістю, довірливістю, доброзичливістю щодо інших людей, терпимістю, поступливістю. Вона вільна від заздрощів, легко ладнає з людьми і добре взаємодіє з колективом. При високих оцінках людина заздрісна, недовірлива, гоноровита. Ї̈̈ інтереси спрямовані на саму себе, вона зазвичай обережна у своїх вчинках, егоцентрична.

Фактор М (практичність-розвинута уява) $\mathrm{M}=5,5$ балів відповідає тестовій нормі, свідчить про практичність, добросовісність, орієнтацію на зовнішню реальність і дотримання загальноприйнятих норм. У 14 слухачів цей показник був $M \geq 8$ балів, що дозволяє говорити про розвинуту уяву, орієнтація на свій внутрішній світ, високий творчий потенціал особистості.

Показник фактору N (прямолінійністьдипломатичність) $\mathrm{N}=4,6$ бала дещо нижчий середнього значення опитувальника Кетелла (5,5 балів), що $\epsilon$ цілком зрозумілим i обгрунтованим у військовому колективі. Він вказує на прямолінійність, природність, безпосередність поведінки. У 25 слухачів показник $\mathrm{N} \geq 8$ бала характеризує їх як розсудливих, проникливих, 3 сентиментальним підходом до подій i оточуючих людей.

Фактор 0 (впевненість у собітривожність) $0=5,46$ бала при середньому значенні 6,6 бала характеризує слухачів в цілому як людей холоднокровних, спокійних, безтурботних, впевнених у собі. У 17 слухачів цей показник виявився $0 \geq 9$ балів (вище коридору норми), що може свідчити про тривожність, деяку депресивність, вразливість особистості.

Експериментальні значення фактора $Q_{1}$ (консерватизм-радикалізм) $\mathrm{Q}_{1}=7,39$ бала дещо нижчі тестового 8,10 бала. Такий показник дає підстави стверджувати про наявність ознак консервативності, дотримання традиційних принципів, віри у визначені постулати, недовірливого ставлення до змін, що будуть брати верх над критичною налаштованістю, схильністю до експери-ментування, відкритістю до сприйняття нових поглядів та змін. Особи з такими особистісними якостями характеризуються більше як виконавці, ніж новатори, що $\epsilon$ значимо для мілітарної структури. Нижчий середнього значення фактор (конформізм - нонконформізм) пристосування $\mathrm{Q}_{2}=4,56$ бала дає можливість стверджувати, що слухачі в цілому дослухаються до громадської думки, віддають перевагу роботі в групі, груповому прийняттю рішення, орієнтуються на соціальне схвалення. При цьому у них часто відсутня ініціатива щодо прийняття рішення. Тільки у 14 слухачів $\mathrm{Q}_{2} \geq 8$ бала, що характеризує їх як осіб незалежних, 3 власною думкою, які прямують самостійно обраним шляхом і не очікують на підтримку і схвалення оточення.

Фактор $\mathrm{Q}_{3}$ (низький самоконтрольвисокий самоконтроль), на відміну від соціальної нормативності поведінки (фактор $0)$, визначає рівень внутрішнього контролю поведінки особи. Його експериментальний результат $\mathrm{Q}_{3}=8,49$ бала - вище верхньої межі, що свідчить про надзвичайно розвинутий самоконтроль слухачів, точність виконання соціальних очікувань. Така особа слідує особистому уявленню, добре контролює свої емоції і поведінку, доводить будь-яку справу до завершення, їй властиві цілеспрямованість та інтегрованість особистості.

Результат експериментального фактору $\mathrm{Q}_{4}$ (розслаблення-напруженість) $\mathrm{Q}_{4}=4,8$ бала нижче тестового 6,0 бала, свідчить про деяку розслабленість, заспокоєність, задоволеність станом речей і обставинами, в яких перебуває слухач, їх незворушливість. Для 66 слухачів $\mathrm{Q}_{4} \leq 4$ бала, що є тривожним сигналом, і вказує на в'ялість, надмірний спокій, низьку мотивацію та лінощі.

Тільки у 21 слухача $\mathrm{Q}_{4} \geq 8$ балів - може свідчити про напруженість, фрустрованість, наявність збудження i неспокою i $\epsilon$ результатом підвищеної мотивації, високої діяльнісної напруженості, незадоволеності станом речей.

Додатково були пораховані показники тривожності $\mathrm{F}_{1}=4,2$ бала; чутливості $\mathrm{F}_{3}=3,11$ бала; конформності $\mathrm{F}_{4}=5,0$ бала. Всі показники нижчі 5,5 бала свідчать про низьку тривожність загалом, низьку чутливість до змін, подій, обставин, що вказує на задоволеність станом речей у цілому, слабку мотивацію для досягнення складних завдань.

Експериментально отримані результати за критеріями дослідження 3 допомогою кластерного аналізу методом $k$-середніх були поділені на дві підгрупи 3 різними психологічними характеристиками.

В результаті такого аналізу було отримано підгрупи з кількістю слухачів - 73 особи у I підгрупі та 62 особи у II підгрупі.

Характеристики цих підгруп наведені в таблиці 2 і на графіку (рис.). Значення факторів B, C, Е, I, N в обох підгрупах суттєво не 
відрізняються ( $>>0,05)$, за іншими факторами можна стверджувати, що підгрупи відрізняються.

Особливо показовими $є$ піки в графічному зображенні профілю кожної підгрупи (див. рис.). Представники першої підгрупи демонструють високе значення показника $\mathrm{MD}=8,28$ бала, що свідчить про надто високу самооцінку, схильність завищувати свої можливості i переоцінювати себе. Представники другої підгрупи більш критично оцінюють свої можливості, їх самооцінка більш адекватна, її експериментальне значення - 7,11 бала. Наступним $€$ показник фактору А (для I підгрупи $A=11,19$ бала, для другої - $A=8,37$ бала). Представників першої підгрупи можна охарактеризувати як більш щирих, безпечних, відкритих, готових до співпраці, комунікативних, здатних легко пристосовуватися. Представники II підгрупи більш, обережні, критичні, точні, об'єктивні, такі, що відстоюють свої погляди та ідеї.

Таблиця 2

Характеристики особистісних якостей слухачів I та II підгруп

\begin{tabular}{|c|c|c|c|c|c|}
\hline $\begin{array}{c}\text { № } \\
\text { фак- } \\
\text { тора }\end{array}$ & $\begin{array}{c}\text { Фак- } \\
\text { тори }\end{array}$ & M1 & M2 & $\sigma_{1}$ & $\sigma_{2}$ \\
\hline 1 & $\mathrm{MD}$ & $8,29^{*}$ & 7,11 & 2,33 & 2,38 \\
\hline 2 & $\mathrm{~A}$ & $11,19^{*}$ & 8,37 & 1,78 & 2,17 \\
\hline 3 & $\mathrm{~B}$ & 4,49 & 4,24 & 1,24 & 1,35 \\
\hline 4 & $\mathrm{C}$ & 6,75 & 6,21 & 1,62 & 1,78 \\
\hline 5 & $\mathrm{E}$ & 7,11 & 6,58 & 2,19 & 2,71 \\
\hline 6 & $\mathrm{~F}$ & $6,78^{*}$ & 6,00 & 2,02 & 2,10 \\
\hline 7 & $\mathrm{G}$ & $9,93^{*}$ & 8,37 & $1,69^{\wedge}$ & 2,26 \\
\hline 8 & $\mathrm{H}$ & $9,73^{*}$ & 7,45 & $1,59^{\wedge}$ & 2,34 \\
\hline 9 & $\mathrm{I}$ & 6,51 & 5,84 & 2,00 & 2,25 \\
\hline 10 & $\mathrm{~L}$ & $3,86^{*}$ & 4,85 & $1,62^{\wedge}$ & 2,14 \\
\hline 11 & $\mathrm{M}$ & $5,11^{*}$ & 5,95 & 2,29 & 2,29 \\
\hline 12 & $\mathrm{~N}$ & 4,52 & 4,69 & 1,94 & 1,96 \\
\hline 13 & $\mathrm{O}$ & $4,11^{*}$ & 7,05 & 2,40 & 2,52 \\
\hline 14 & $\mathrm{Q} 1$ & $7,89^{*}$ & 6,81 & 2,10 & 2,11 \\
\hline 15 & $\mathrm{Q} 2$ & $3,88^{*}$ & 5,87 & 1,89 & 2,18 \\
\hline 16 & $\mathrm{Q} 3$ & $8,96^{*}$ & 7,93 & $1,43^{\wedge}$ & 1,85 \\
\hline 17 & $\mathrm{Q} 4$ & $4,19^{*}$ & 5,52 & 2,18 & 2,58 \\
\hline
\end{tabular}

Примітка: позначення як в таблиці 1.

* - наявність різниці середніх M1 та M2 за критерієм $\mathrm{t} \mathrm{Стьюдента} \mathrm{на} \mathrm{рівні} \mathrm{p} \leq 0,05$; $^{\wedge}$ - наявність різниці дисперсій $\left(\sigma_{1}{ }^{2}\right.$ та $\left.\sigma_{2}{ }^{2}\right)$ за критерієм F Фішера на рівні $\mathrm{p} \leq 0,05$.

В цілому групу I можна охарактеризувати як довірливі, внутрішньо розслаблені, незалежні, доброзичливі у ставленні до інших, добре працюють в колективі, не зважають на зауваження $(\mathrm{L}=3,86$ бала); безпечні, самовпевнені, самонадіяні, енергійні, життєрадісні, спокійні, нечутливі до хвали чи критики $(0=4,11$ бала); критично налаштовані,

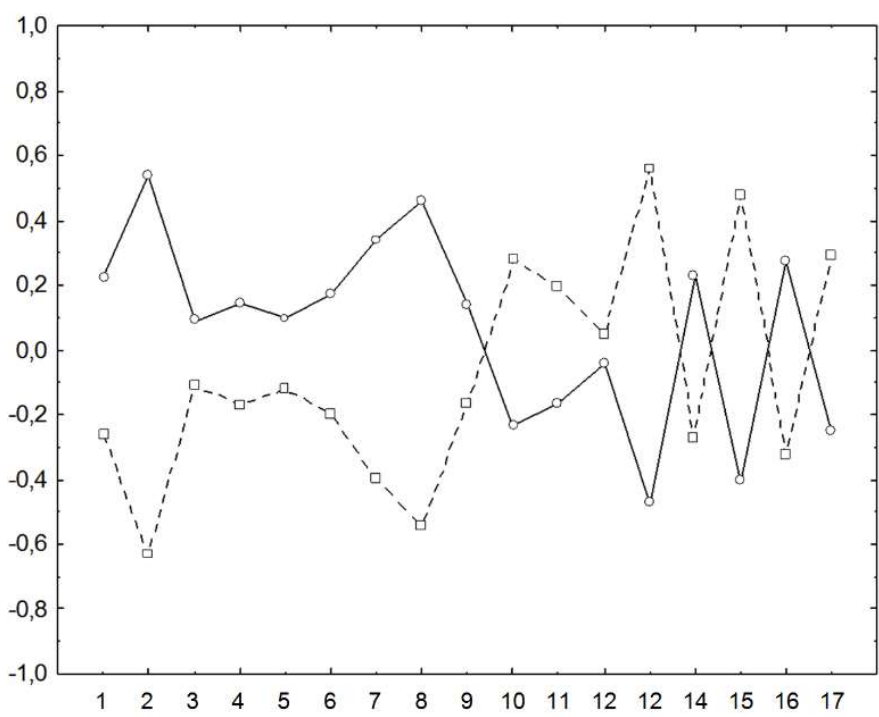

\section{- I підгрупа; - - - - - II підгрупа}

На осі абсцис - відповідні особистісні якості від 1 до 17 (позначення шкал в табл. 2). На осі ординат - стандартизовані рівні особистісних якостей слухачів. Номери шкал 1 - 17 тесту Р.Кеттела (як в табл. 2).

Рисунок. Особливості профілів особистості у представників підгруп I та II.

терплячі до незручностей, характеризуються наявністю інтелектуальних інтересів, аналітичністю мислення, не довіряють авторитетам, нічого не сприймають на віру $\left(Q_{1}=7,89\right.$ бала); залежні від групи, рішення приймають з іншими, залежні від громадської думки $\left(\mathrm{Q}_{2}=3,88\right.$ бала); вольові, діють за усвідомленим планом, мають лідерські задатки, сприймають соціальні норми, контролюють свої емоції і поведінку, доводять справу до завершення $\left(Q_{3}=8,96\right.$ бала); можуть бути розслаблені, ліниві, 3 низькою мотивацією $\left(Q_{4}=4,19\right.$ бала).

Такі характеристики цілком відповідають професіограмі військовослужбовця. Тому представників цієї підгрупи можна умовно назвати «активними».

Представників другої підгрупи можна охарактеризувати як ( $\mathrm{L}=4,85$ бала) внутрішньо напруженими, вразливими до невдач, обережними у вчинках; $(0=7,05$ бала) 3 сильним почуттям обов'язку, чутливими до оцінки інших, дещо усамітненими; $\left(Q_{1}=6,81\right.$ бала) як осіб, які мають і дотримуються уставлених поглядів, 3 обережністю ставляться до нових ідей, людей, дій, віддають 
перевагу традиційним нормам поведінки; $\left(\mathrm{Q}_{2}=5,87\right.$ бала) в цілому самодостатні, незалежні від групи, самостійні; $\left(Q_{3}=7,93\right.$ бала) діють за власними уявленнями, не завжди зважають на загальні правила, наявна внутрішня конфліктність уявлень про себе; $\left(Q_{4}=5,52\right.$ бала) зібрані, активні, вмотивовані, не зважаючи на втому, дещо дратівливі. Слухачів цієї підгрупи можна умовно назвати «обережними».

Порівнявши середній показник балу диплому слухачів першої і другої підгруп, ми виявили, що представники другої підгрупи мали достовірно вищий середній бал - 4,18,

\section{Висновки}

1. Слухачі першого курсу факультету підготовки військових лікарів Української військово-медичної академії у цілому задоволені своїм становищем, кризи професійного самовизначення у них не спостерігається, професійний вибір здійснено усвідомлено, професійні експектації цілком очікувані.

2. Визначені у слухачів особистісні характеристики в цілому підтверджують наявність професійно значимих для військового медика рис характеру: самовпевненість, високі розумові здібності, кмітливість, наявність абстрактного мислення, товариськість, домінантність, стриманість, емоційна стійкість, самостійність, незалежність в судженнях та в поведінці, усвідомлена висока нормативність поведінки, осмислене дотримання норм і правил, наполегливість у досягненні мети, відповідальність, мужність, розсудливість, довірливість, доброзичливість щодо інших людей.

3. Досліджена група $\epsilon$ суттєво неоднорідною за комплексом особистісних якостей: замкнутість-товариськість, стриманість-експресивність, нерішучість-сміливість, довірливість-підозрілість, практичністьрозвинута уява, впевненість у собітривожність, консерватизм-радикалізм, конформізм-нонконформізм, низький самоконтроль-високий самоконтроль, розслаблення-напруженість. Слухачі підгрупи

\section{Література}

1. Александров Д.В., Солоненко А.М. Професійні еспектації студентства в умовах освітньої реформи: методологічний аспект// Versus . - 2014. - №2(4). С.45-49.

2. Військовослужбовець - професія для ніж представники першої підгрупи - 4,04 $(\mathrm{p}<0,04)$.

Визначивши середній бал успішності серед представників двох підгруп за перший рік навчання в УВМА, достовірної різниці серед цих значень не виявлено (середній бал успішності I підгрупи - 4,17, середній бал успішності II підгрупи - 4,26). Причому успішність в обидвох підгрупах зросла, що може свідчити або про підвищення інтересу до профільних предметів, або про можливе зменшення вимогливості викладачів і менш об'єктивне оцінювання навчальної діяльності слухачів.

«обережних» характеризуються як більш вразливі до невдач, обережні, 3 сильним почуттям обов'язку, чутливі до оцінки оточуючих, дещо усамітнені, мають достовірно вищі результати навчання в порівнянні з слухачами підгрупи «активних». Слухачі підгрупи «активних» $€$ більш комунікабельними, що $\epsilon$ певною перевагою для військової служби. Для представників цієї підгрупи більшу увагу потрібно приділяти якості їх навчання.

4. Підвищення рівня успішності серед слухачів першого курсу у порівнянні 3 їх успішністю в університеті може свідчити про бажання слухачів вивчати предмети професійного спрямування або про можливу знижену вимогливість при оцінюванні результатів навчання слухачів. Щоб уникнути останнього необхідно посилити об'єктивні вимоги до оцінки успішності слухачів, запровадивши різноманітні форми контролю, особливо комп'ютеризовані тестові завдання.

5. Актуальним завданням для подальшого удосконалення процесу навчання $\epsilon$ цілеспрямоване управління процесом формування професійного світобачення. При організації навчально-виховного процесу для слухачів важливо робити акцент на індивідуальних завданнях, 3 посиленням різноманітних форм контролю. Доцільно створювати навчальні групи відповідно до середнього балу навчання слухачів.

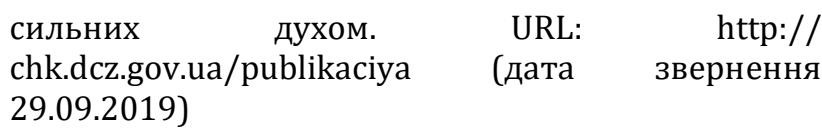

3. Діагностика індивідуально-психологічних властивостей особистості: Навчально-методичний 
посібник / А.Б.Неурова, О.С.Капінус, Т.Л.Грицевич. Львів: НАСВ, 2016. - 181 с.

4. Каземіренко В.П. Програма дослідження психосоціальних чинників молодої людини до навчання у ВНЗ та майбутньої професії / В.П.Каземіренко //Практична психологія та соціальна робота. - 2004. - №6 - С.76-78.

5. Колісник-Гуменюк Ю.І., Гуменюк В.В. Особистісна характеристика медичного працівника /неперервна професійна освіта: теорія і практика. - Випуск 1-2(42-43). Серія: Педагогічні науки.- Київ :ТОВ «Едельвейс». - 2015. - С.72-77.

\section{References}

1. Alexandrov, D.V., Solonenko A.M. (2014). Professional views of students in terms of educational reform: methodological aspect. Versus. 2 (4). 45-49.

2. A serviceman is a profession for the strong in spirit. URL: http://chk.dcz.gov.ua/publikaciya (access date 29.09.2019).

3. Neurova, A.B., Kapinus, O.S., Gritsevich, T.L. (2016). Diagnosis of individual psychological properties of personality: Educational and methodical manual. Lviv: NASV, 181p.

4. Kazemirenko, V.P. (2004). Program of research of psychosocial factors of a young person before studying at a university and future profession. Practical psychology and social work. №6. 76-78.

5. Kolisnyk-Humeniuk, Y.I., Humeniuk, V.V. (2015).
6. Малинович Л.М. Адаптація студентіввипускників до професійної діяльності// Науковий вісник. Львівський державний університет внутрішніх справ. - 2012. - №2(2). - С.213-221

7. Професійно важливі якості особистості. URL: http:// edu.medlib.dp.gov.ua/?page_id=1178 (дата звернення 28.09.2019).

8. Щербакова I. М. Соціально-психологічні аспекти духовної кризи особистості у процесі її професійного самовизначення / І.М.Щербакова // Вісник післядипломної освіти. - 2012. - Вип. 6. - С. 439-446.

Personal characteristics of a medical worker. Continuing professional education: theory and practice. Iss. 1-2 (42-43). Series: Pedagogical sciences. Kyiv: Edelweiss LLC. 72-77.

6. Malinovich, L.M. (2012). Adaptation of graduate students to professional activity. Scientific herald. Lviv State University of Internal Affairs. №2 (2). 213-221.

7. Professionally important personality traits. URL: http://edu.medlib.dp.gov.ua/?page $\mathrm{id}=1178$ (access date 28.09.2019).

8. Shcherbakova, I.M. (2012). Socio-psychological aspects of the spiritual crisis of the individual in the process of her professional self-determination Bulletin of postgraduate education. V.6. 439-446.

\title{
ЛИЧНОСТНЫЕ СВОЙСТВА СЛУШАТЕЛЯ КАК ПРЕДПОСЫЛКИ ПРОФЕССИОНАЛЬНОГО СТАНОВЛЕНИЯ И УСПЕШНОЙ АДАПТАЦИИ ВОЕННЫХ МЕДИКОВ
}

\section{И.С. Тринька' ${ }^{1}$ В.В. Кальниш ${ }^{1}$, Н.И. Мудрик ${ }^{1}$, В.о. Волошин ${ }^{2}$}

\author{
1 Украинская военно-медицинская академия, г. Киев, Украина \\ ${ }^{4}$ Национальная академия Службы безопасности Украины, г. Киев, Украина.
}

Введение. Профессиональная подготовка личности военного врача является динамическим процессом профессионального самоопределения, связанным с личностными кризисными явлениями. Причинами внутриличностных конфликтов в процессе получения профессионального образования является низкий адаптивный уровень психических возможностей личности, не соответствует требованиям учебной деятельности и проявляется в высоком уровне тревожности, агрессивности.

Целью исследования было определение личностных характеристик и проверка уровня адаптационных возможностей слушателей - будущих военных врачей.

Материалы и методы. Использовалась методика многофакторного исследования личности P. Кеттела (16 РF опросник). Статистический анализ полученных результатов проводился методом вариационной статистики и кластерного анализа.

Результаты. Экспериментальные данные с помощью кластерного анализа методом $k$-средних были разделены на две подгруппы с разными психологическими характеристиками по комплексу личностных качеств, которые условно были названы «активные» и «осторожные». Установлено, что слушатели подгруппы «осторожных» характеризуются как более уязвимые к неудачам, осторожны, с сильным чувством долга, чувствительны к оценке окружающих, несколько уединенные, имеют достоверно более высокие результаты обучения по сравнению со слушателями подгруппы «активных», а слушатели подгруппы «активных» более коммуникабельными, что является определенным преимуществом для военной службы. Для представителей этой подгруппы большее внимание нужно уделять качеству их обучения. Показано, что определенные у слушателей личностные характеристики в целом подтверждают наличие у них профессионально значимых для военного медика черты характера: самоуверенность, высокие умственные способности, сообразительность, наличие абстрактного мышления, общительность, доминантность, сдержанность, эмоциональная устойчивость, самостоятельность, 
независимость в суждениях и в поведении, осознанная высокая нормативность поведения, осмысленное соблюдение норм и правил, настойчивость в достижении цели, ответственность, мужество, рассудительность, доверчивость, доброжелательность в отношении других людей.

Выводы. Предложено актуальные пути дальнейшего совершенствования учебного процесса и управления процессом формирования профессионального мировоззрения у слушателей факультета подготовки военных врачей Украинской военно-медицинской академии.

Ключевые слова: профессиональное самоопределение, профессиональные експектации, профессиональное становление военного медика, личностные свойства, опросник Кеттела, профессионально значимые качества.

\title{
STUDENTS' PERSONAL CHARACTERISTICS AS A PREREQUISITE FOR PROFESSIONAL FORMATION AND SUCCESSFUL ADAPTATION OF A MILITARY MEDIC
}

\author{
I.S. Trinka1, V.V. Kalnysh'1, N.I. Mudryk¹, V.0. Voloshyn² \\ ${ }^{1}$ Ukrainian Military Medical Academy, Kyiv, Ukraine \\ ${ }^{2}$ National Academy of Security Service of Ukraine, Kyiv, Ukraine
}

Introduction. The professional training of a military doctor is a dynamic process of professional selfdetermination associated with personal crisis phenomena. The causes of intrapersonal conflicts in the process of obtaining professional education are the low adaptive level of mental capabilities of the individual, which does not meet the requirements of educational activities and is manifested in a high level of anxiety, aggression.

The purpose of the study was to determine the personal characteristics and test the level of adaptive capacity of students - future military doctors.

Materials and methods. The method of multifactorial study of R. Kettel's personality was used (16 RF questionnaire). Statistical analysis of the obtained results was performed by the method of variation statistics and cluster analysis.

Results. Experimental data using cluster analysis by the method of $k$-means were divided into two subgroups with different psychological characteristics according to a set of personal qualities, which were conventionally called «active» and «cautious». It was found that students of the subgroup «cautious» are characterized as more vulnerable to failure, cautious, with a strong sense of duty, sensitive to the assessment of others, somewhat lonely, have significantly higher learning outcomes than students of the subgroup «active», and students of the subgroup active "are more communicative, which is a certain advantage for military service. Representatives of this subgroup need to pay more attention to the quality of their education. It is shown that the personal characteristics identified in the students generally confirm the presence of professionally significant for the military medic character traits: selfconfidence, high mental abilities, intelligence, the presence of abstract thinking, sociability, dominance, restraint, emotional stability, independence, independence in judgments and in behavior, conscious high normative behavior, meaningful observance of norms and rules, persistence in achieving the goal, responsibility, courage, prudence, trust, kindness to other people.

Conclusions. The actual ways of further improvement of the educational process and management of the process of formation of professional worldview at the students of the faculty of training of military doctors of the Ukrainian Military Medical Academy are offered.

Keyword: professional self-determination, professional expectations, professional development of a military medic, personal qualities, Kettel's questionnaire, professionally significant features.

Конфлікт інтересів: відсутній.

Conflicts of interest: authors have no conflict of interest to declare.

\section{Відомості про авторів:}

Трінька I.C. C,E,F- полковник медичної служби, кандидат медичних наук, доцент, начальник кафедри авіаційної, морської медицини та психофізіології Української військово-медичної академії, м. Київ.

Кальниш В.В. A,C,D,E, - доктор біологічних наук, професор, професор кафедри авіаційної, морської медицини та психофізіології Української військово-медичної академії, м. Київ.

Мудрик H.I. A,B,C,D -кандидат педагогічних наук, доцент, доцент кафедри авіаційної, морської медицини та психофізіології Української військово-медичної академії, м. Київ.

Волошиин B.O. C,D,E - доктор медичних наук, професор, професор спеціальної кафедри - 15 Національної академії Служби безпеки України, м. Київ.

$A$ - концепція та дизайн дослідження; B - збір даних; C - аналіз та інтерпретація даних; D написання статmi; $E$ - редагування статmi; F- остаточне затвердження статті. 


\section{Сведения об авторах:}

Тринька И.С. - полковник медицинской службы, кандидат медицинских наук, доцент, начальник кафедры авиационной морской медицины и психофизиологии Украинской военно-медицинской академии, г. Киев;

Кальниш В.В. - доктор биологических наук, профессор, профессор кафедры авиационной морской медицины и психофизиологии Украинской военно-медицинской академии., г. Киев.

Мудрик Н.И. - кандидат педагогических наук, доцент, доцент кафедры авиационной морской медицины Украинской военно-медицинской академии, г. Киев.

Волошиин В.А. - доктор медицинских наук, профессор, профессор специальной кафедры - 15 Национальной академии Службы безопасности Украины, г. Киев.

Information about the authors:

Trinka I.S. C,E,F -Colonel of Medical Service, Candidate of Medical Sciences, Associate Professor, head of the department of Aviation, Maritime Medicine and Psychophysiology of the Ukrainian Military Medical Academy, Kyiv, https://orcid.org/0000-0002-9095-8321.

Kalnysh V.V. A,C,D,E, - Doctor of Biological Sciences, Professor, Professor of the Department of Aviation, Marine Medicine and Psychophysiology of the Ukrainian Military Medical Academy, Kyiv, https://orcid.org/0000$\underline{0002-5033-6659}$.

Mudryk N. I.A,B,C,D - Candidate of Pedagogical Sciences, Associate Professor, Associate Professor of Aviation, Maritime Medicine and Psychophysiology of the Ukrainian Military Medical Academy, Kyiv, https://orcid.org/0000-0003-4909-8850.

Voloshyn V.0. C,D,E - Doctor of medical sciences, professor, professor of special department - 15 of the National Academy of Security Service of Ukraine, Kyiv.

$A$ - research concept and design; $B$ - collection and/or assembly of data; $C$ - data analysis and interpretation; $D$ - writing the article; $E$ - critical revision of the article; $F$ - final approval of the article.

Адреса для листування: вул. Московська, 45/1, буд. 33, м. Київ 01015 